\title{
Assessment of Costs in Harvesting Systems Using WoodChainManager Web-based Tool
}

\author{
Matevž Triplat, Nike Krajnc
}

\begin{abstract}
The rationalization of working procedures during difficult market conditions is gaining increasing importance. For rational production, it is necessary to always be aware of what and how much to invest in the business process to obtain the desired products or services without economic loss. This article presents a tool for the assessment of costs in forest wood supply chains. WoodChainManager is a Web-based tool composed of three user modules intended for the assessment of material costs of individual machines or the total costs of all selected machines in a forest harvesting system. Users can test the impact of individual technologies on the total material costs of the harvesting system and thus optimize operation processes. The basic tool for describing harvesting systems is the matrix, which visualizes cutting and hauling from the standing tree in the stand to the forest products at the end user. The tool has built-in algorithms that prevent the selection of an illogical harvesting system. The selected method for calculating costs for individual machines is simple, but still reflects the state of the actually incurred costs. WoodChainManager offers cost calculations for a wide range of technologies, machines and appurtenant attachments. The authors of this paper wish to increase awareness and understanding of cost calculations and to offer the possibility to directly compare different harvesting systems.
\end{abstract}

Keywords: calculations, costs, norms, harvesting system, optimization, model

\section{Introduction}

Forestry as a branch of industry is not intended to be an end in itself, but regarded as one of the links in the complex forest wood supply chain. From a technological aspect, the forestry links of the forest wood supply chain are made up of a series of production processes through which the natural resources from forests are transformed into products and services (Triplat et al. 2013). Similar to all other branches of industry, the objective of timber production is to select the most rational working techniques and procedures and the most comprehensive technological solutions. The cost of labour per unit time and productivity determine the price, which is the basis for comparison of different harvesting systems (Krč and Košir 2004). For rational production, one should always be aware of what and how much to invest in the business process to obtain the desired products or services without economic loss. Calculations enable the comparison of individual and total costs between products or services and thus offer a choice of measures to reduce costs and increase business efficiency and profitability (Winkler et al. 1994). It is necessary to calculate the costs of machine work in forestry in order to assess (i) whether, and to what extent, it is worth opting for machine work instead of manual work; (ii) whether, and to what extent, newer and more complex technology is more effective than existing technology; (iii) which technology and techniques are more favourable with respect to work and organizational approaches; (iv) the difference in costs, when using the same technology, between different organizational forms of work, operating units, companies, etc. and the reason for this difference; (v) the price of machine work when carrying out services or the price of hired machines compared with the price of own machines; and (vi) material compensation or reimbursement to the worker when the machine is the worker's property or when the worker maintains it partially or fully (Winkler et al. 1994, Akay 1998). 


\section{Overview of Existing Studies}

Calculation of costs in forestry began in the early $20^{\text {th }}$ century when machines were introduced in timber production and there was a need to evaluate operating, investment and labour costs. Machine costs were calculated using standard economic methods, with costs being divided into fixed asset costs and operating costs (Ackerman et al. 2014). Various methods for the calculation of forest mechanization costs were developed, beginning with Matthews (1942) and eventually leading to more influential works in the early 1980s (Miyata 1980, Sundberg and Silversides 1988, FAO 1992, Ackerman et al. 2014). Studies have shown slightly different results with respect to various methodologies (e.g. Klun et. al. 2007, Bilek 2009, Sperandio 2010, Pilz and Erler 2017). The methods have a common background in the structuring of calculation parameters, but differ in the manner of calculation and consideration of individual parameters, e.g. machine rates, salvage value, repair costs and consideration of the costs of tyres and tracks.

Calculation methods were developed for different objectives. Most calculations were based on either one of two main objectives: to establish the cost of a particular machine or to set a price for the work done with the machine (Ackerman et al. 2014). Recently, these calculations, and an increasing number of tools based on them, have been adapted for the needs of various target groups. The development of the tools is based on various software solutions, including MS Excelbased spreadsheet tools, Windows Applications and Web applications. Perhaps best known in the first category are COST calculations, the main idea of which is to establish uniform calculations of costs in the production of wood biomass. The emphasis on uniformity enables comparison of research results. The Microsoft Excel-based spreadsheet model is easy to understand and use and gives users a simultaneous view of the input parameters and resulting cost outputs (Ackerman et al. 2014).

Among the set of Windows-based applications, the HeProMo tool is a good example. HeProMo is a timber harvesting productivity model used to calculate the costs and time needed for different harvesting operations. Its modular construction allows the calculation of both individual technology and entire harvesting systems. It is aimed at forestry companies, loggers, forestry administrations and training institutes, and developers of software for forestry applications (Nemestothy 2014). Another good example of a Windows-based tool is ECOCOST. The ECOCOST model utilizes basic cost calculation principles, which can be applied to various types of forest machines and ma- chine models. Estimation of productivity under given conditions is limited to a harvester and forwarder harvesting system (Lan 2001). Finally, there are Webbased tools, which include examples such as the Forstmachinen database by the Austrian Research Centre for Forests (BFW) and John Deer calculations (Cwiertnia et al 2014, Deere\&Co 2018). The BFW is a database of more than 700 forest machines with associated costs calculated according to three calculation methods: BFW, Kuratorium für Waldarbeit und Forsttechnik e.V. (KWF) and the Food and Agriculture Organization of the United Nations (FAO).

\section{Theoretical Analysis}

The quality of a calculation depends on the quality of the input data. However, quality data are hard to provide without constant investment and updating. At work, we are constantly faced with issues related to the rationalization of costs and productivity. In this paper, we present a Web-based tool for preliminary assessment of forestry operation costs. The tool, called WoodChainManager (WCM), is publically available on the Web for all Internet users (WCM 2018).

The purpose of WCM is, on the one hand, to calculate operational costs for working with a selected machine and, on the other hand, to set the price of service or product for the work carried out with a wider range of forest machines. Calculation provides useful information on the costs of a certain technology, as well as on the entire harvesting system.

The main advantage of the Web-based tool is the fact that it is publicly available and therefore offered for wide use. Users have the possibility to compare cost calculations with other users. Moreover, WoodChainManager is regularly updated in terms of default values.

\section{Materials and Methods}

To describe the harvesting system, the idea of visualization of »functiograms « has been utilized. It was recently developed by prof. Joern Erler (Erler and Weiß 2003, Erler and Dög 2009), who presented it within the framework of Kuratorium für Waldarbeit und Forsttechnik e.V. (KWF) for comparison of hauling methods and subsequently offered it for wider use.

The basic tool for describing harvesting systems is the matrix, which visualizes cutting and hauling from the standing tree in the stand to the forest products at the end user. On the ordinate axis, the changes in the state of tree processing are depicted (standing tree, 
stemwood and logging residues, roundwood (assortments), woodchips). On the abscissa axis, the course of hauling or transport is presented, from the standing tree via different categories of forest roads, to loading areas on forest roads and finally to the end user (wood processing centre, sawmill, boiler room, etc.). Intersections in the matrix indicate the place where certain operations are carried out or where the state of tree processing changes (limbing or crosscutting, for example, can be implemented in the stand on a skid-road or even a forest road) (Triplat et al. 2015). While using the online tool, it is important that the user maintains constant control over the operations carried out in the production of wood.

The user chooses which operations will be performed or included in the harvesting system (cutting, limbing, bucking, wood chipping or log splitting and hauling or transporting) as well as the location where the selected set of operations will be carried out (forest stand, skid trail, skid road, forest road, end user). The online tool proposes a whole range of possible technologies with which the selected operations can be carried out at selected localities. When dealing with operations that envisage further moves along forest roads (hauling/transport), the location where the transport will end (skid road, forest road, end user) must be defined as well. The online tool's algorithm uses logical controls, which prevent the user from selecting illogical harvesting systems. The user can choose between several different machines and additional equipment such as different types of installations for tractors (winches, forest trailers, etc.), as well as additional equipment for tractors (tractor safety cage, wheel chains, etc.). WCM embraces a wide range of techniques and tools: chain saws (standard, electric, one-handed), tools and personal protective equipment, chain saw winches, agricultural tractors, forest skidders, tractor equipment (wheel chains, tractor safety cage), 3-point winches, forestry caterpillar tractors, forestry trailers and cranes, harvesters and forwarders, woodchippers, log splitters, firewood processers, forestry trucks and trailers for transport of roundwood or woodchips, and cable cranes. Apart from the calculation of material costs and visualization of harvesting systems, WCM enables calculation of labour costs and calculation of productivity for a narrower range of techniques.

Prior to the implementation of software solutions, several calculation methods were studied: Food and Agriculture Organization (FAO); Kuratorium für Waldarbeit und Forsttechnik (KWF), the »Machine Cost Calculation Model«, which was produced by an international group of experts operating within the framework of COST Action FP0902; Kuratorium für Technik und Bauwesen in der Landwirtschaft e.V. (KTBL); Österreichisches Kuratorium für Landtechnik und Landentwicklung - ÖKL (Austria); and Agroscope Tönikön (Switzerland). We opted for the method already used in Slovenia for the calculation of costs in the »Rules on the list of agricultural and forestry machinery and the catalogue of costs of agricultural and forestry machinery « (Rules on..., 2016). It is based on the Austrian method for the calculation of machine costs in agriculture (ÖKL, 2014) and described in the following sections.

Total cost $(€ / \mathrm{h})$ includes all fixed costs $(€ / \mathrm{h})$ and variable costs together $(€ / \mathrm{h})$

$$
C_{\text {tot }}=C_{\text {fix }}+C_{\text {var }}
$$

Where:

$C_{\text {tot }}$ total cost of the selected mechanization, $€ / \mathrm{h}$

$C_{\text {fix }}$ fixed costs (such as depreciation, interest on invested capital, insurance and storage), $€ / h$

$C_{\text {var }}$ variable costs (such as maintenance, fuel and lubricants), $€ / \mathrm{h}$.

Fixed costs $\left(C_{\text {fix }}\right)$ are calculated by the following equation:

$$
C_{\text {fix }}=\frac{P V / D E+I \times P V}{A U}
$$

Where:

$P V$ purchase vale (in $€$ ), where the average weighted purchase value of a group of machines takes into account market share

$D E$ depreciation (in years), which is calculated in view of the factual period of possible use of individual groups of machines before they are worn out or become technologically outdated

I interest on funds invested (in \%), which includes storage and insurance. On an average annual basis, half of the interest rate on invested capital (4\%) is taken into account, and the rest is represented as the share of costs for storage and insurance $(2 \%)$

$A U$ annual use (number of hours), which enables calculation of fixed costs per hour.

Variable costs $\left(C_{\mathrm{var}}\right)$ are composed of maintenance costs $\left(C_{\text {maint }}\right)$ and fuel and lubricant costs $\left(C_{\text {fuel }}\right)$

$$
C_{\text {var }}=C_{\text {maint }}+C_{\text {fuel }}
$$

Maintenance costs $\left(C_{\text {maint }}\right)$ are calculated according to the following equation:

$$
C_{\text {maint }}=\frac{M_{\mathrm{r}} \times P V}{100}
$$


Where:

$M_{\mathrm{r}}$ factor of maintenance $(0.8-15 \% / 100 \mathrm{~h})$, which is an estimated value and indicates the average cost of maintenance as a percentage of the machine purchase value

Fuel and lubricant costs $\left(C_{\text {fuel }}\right)$ are calculated according to the following equation:

$$
C_{\text {fuel }}=\left(100 \%+L_{\mathrm{r}}\right) \times U_{\mathrm{r}} \times\left(F_{\text {cons }} \times E P\right) \times F_{\text {price }}
$$

Where:

$L_{\mathrm{r}} \quad$ cost of lubricant (in \%) and is estimated at 20\% of fuel costs. An exception is the chain saw, where costs are higher $(30 \%)$ due to chainsaw lubrication oil

$U_{\mathrm{r}}$ engine load (in \%), which is estimated at 70\% for chain saws and $40 \%$ for other machines

$F_{\text {cons }}$ factor for specific fuel consumption (0.33 1/ $\mathrm{kWh}$ ), which accounts for the relationship between engine power and fuel consumption (ÖKL 2014)

$E P$ engine power (in $\mathrm{kW}$ )

$F_{\text {price }}$ current price of fuel (diesel or gasoline) (in $€$ ). Prices of fuel are regularly automatically updated via Web interface. However, the user can always independently adjust the price of fuel.

Apart from categorization based on technology, machines are categorized per size class according to engine power, load capacity or other technical charac-

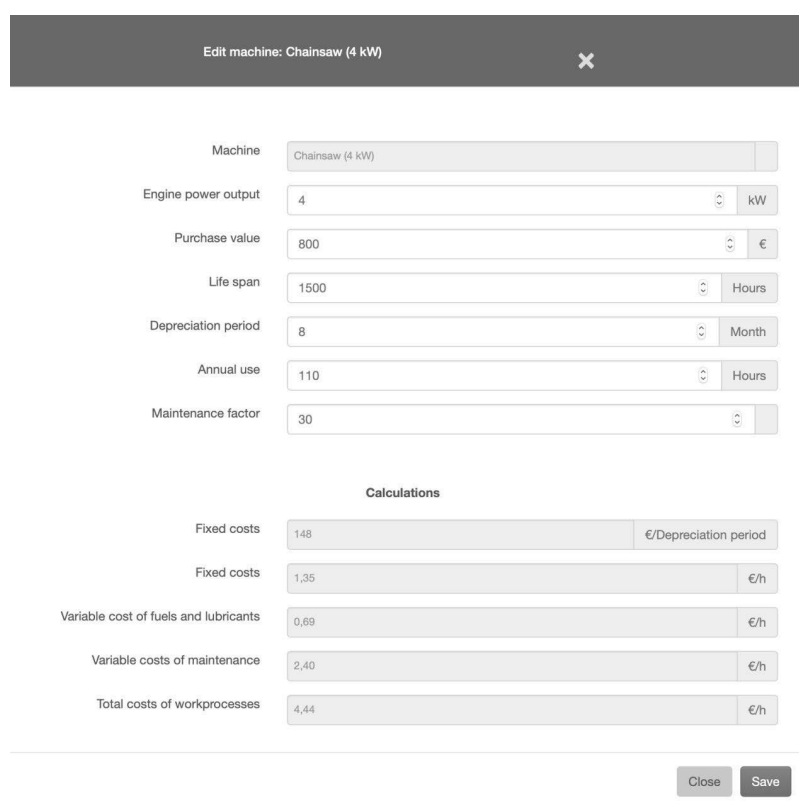

Fig. 1 Editing the calculation parameters in the WCM online tool teristics. The online tool offers a wide range of different techniques or machines.

Users may configure, at their own discretion, the majority of input data for the calculation of costs of individual machines (Fig. 1) and replace the proposed adopted average values with their own data (purchase value, annual use, etc.). The costs of individual machines are summed up in the total cost per entire harvesting system (Table 1 ).

For each selected technique, users have the possibility to specify the number of workers who conduct the selected operation and the hourly rate of labour

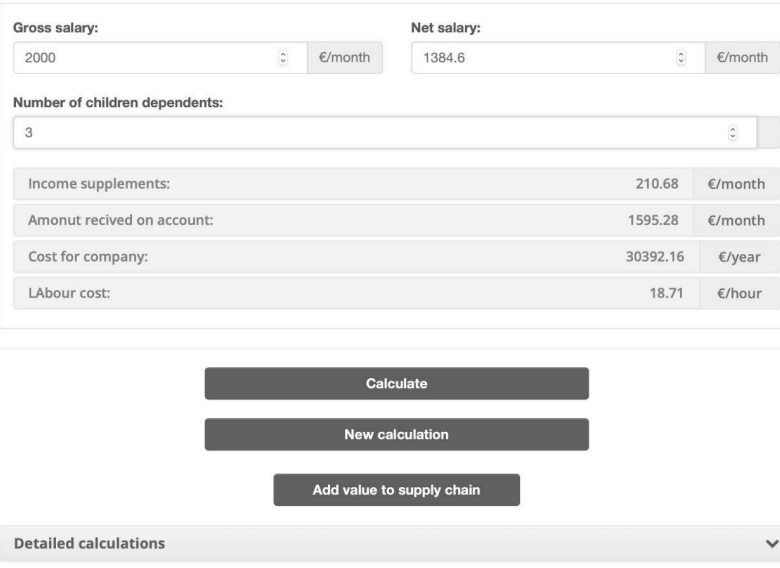

Fig. 2 Tool for the calculation of labour costs

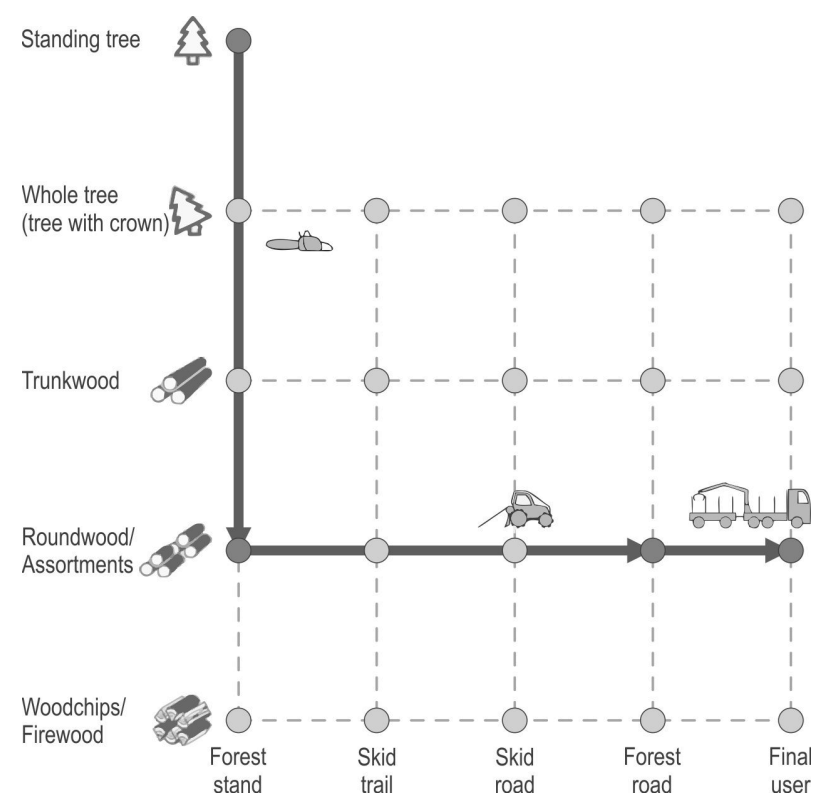

Fig. 3 Visualization of timber production with chainsaw cutting, tractor hauling and transport of roundwood with forestry trucks to the end user 
Table 1 Calculation of costs incurred during chainsaw cutting and tractor hauling, followed by transport of roundwood with forestry trucks to the end user

\begin{tabular}{|c|c|c|c|c|c|c|c|c|}
\hline Machine & 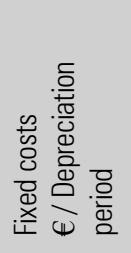 & 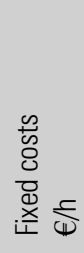 & 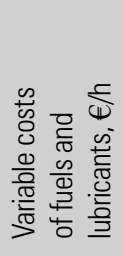 & 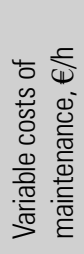 & 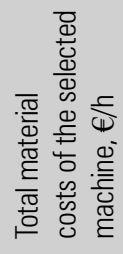 & 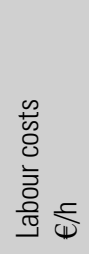 & 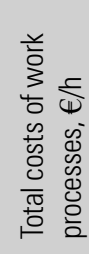 & 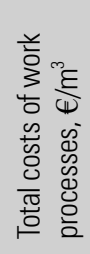 \\
\hline Chainsaw, 4 kW & 148.00 & 1.35 & 0.73 & 2.40 & 4.48 & \multirow{2}{*}{12.91} & \multirow{2}{*}{18.36} & \multirow{2}{*}{7.34} \\
\hline Small tools and personal protective equip & 111.00 & 0.56 & 0 & 0.42 & 0.98 & & & \\
\hline 4WD agricultural tractor, 75-94 kW & 6811.00 & 13.62 & 16.23 & 3.34 & 33.19 & \multirow{5}{*}{15.92} & \multirow{5}{*}{65.40} & \multirow{5}{*}{18.69} \\
\hline Cabin protection (complete) & 2365.00 & 4.73 & 0 & 1.32 & 6.05 & & & \\
\hline Wheel chains for mud, $28^{\prime \prime}-32^{\prime \prime}$ & 143.33 & 1.79 & 0 & 0.50 & 2.29 & & & \\
\hline Two drum winch, 8 ton & 974.67 & 3.48 & 0 & 2.72 & 6.20 & & & \\
\hline Radio remote control & 172.00 & 1.27 & 0 & 0.48 & 1.75 & & & \\
\hline $\begin{array}{l}\text { Semi-truck with trailer and crane for } \\
\text { roundwood, } 300 \mathrm{~kW}\end{array}$ & $33,000.00$ & 33.30 & 57.28 & 14.80 & 105.38 & 17.43 & 122.81 & 4.91 \\
\hline
\end{tabular}

costs. The latter can be calculated with the aid of the tool, which calculates the costs of a worker on the basis of Slovenian legislation (Fig. 2). The data input requested by the Web tool for calculating hourly labour costs is gross (or net) monthly salary. On the basis of minimal conditions (paid annual leave, meal fees, travel costs, etc.), the online tool calculates the cost of the worker at the company's expense. These inputs can also be adapted with corrections of the effective working time, designation of the actual costs associated with the work (business trips, meal fees, longterm service benefits, etc.), designation of other costs associated with employment rights (annual leave al- lowance, the provision of safety and health at work, other costs), and designation of tax deductions.

For the calculation of costs per unit of product, it is necessary to know the consumption of time per working process and the quantity of products that are made as a consequence of a certain working process. The direct relationship between the quantity of products and the time needed is called productivity. With the WCM online tool, technical norms can be stipulated for a specifically defined worksite. The tool for determining the norms of forestry operations is methodologically defined in the Official Gazette under the Decree on the concession for the exploitation of forests owned by the Republic of Slovenia (Decree on the concession... 2010).

Table 2 Calculation of costs for fully mechanized harvesting, which is followed by transport of roundwood with forestry trucks

\begin{tabular}{|c|c|c|c|c|c|c|c|c|}
\hline Machine & 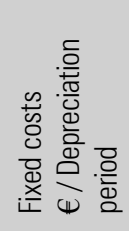 & 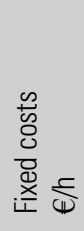 & 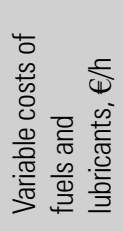 & 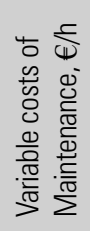 & 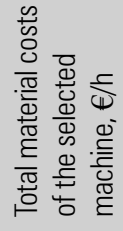 & 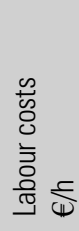 & 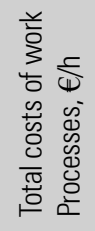 & 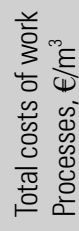 \\
\hline Harvester, 140 kW & $48,733.33$ & 54.15 & 26.73 & 34.00 & 114.88 & 18.18 & 133.06 & 10.24 \\
\hline Forwarder, $125 \mathrm{~kW}$ & $48,000.00$ & 48.00 & 26.73 & 30.00 & 104.73 & 18.18 & 122.91 & 8.19 \\
\hline $\begin{array}{l}\text { Semi-truck with trailer and } \\
\text { crane for roundwood, } 300 \mathrm{~kW}\end{array}$ & $33,300.00$ & 33.30 & 57.28 & 14.80 & 105.38 & 17.43 & 122.81 & 4.91 \\
\hline
\end{tabular}




\section{Results}

Below is an example of WCM cost calculations. Table 1 presents costs incurred during chainsaw cutting and tractor hauling, followed by transport of roundwood with forestry trucks, while Fig. 3 presents the visualization of the harvesting system. Table 2 presents the calculation of costs for the case of fully mechanized harvesting followed by transport of roundwood with forestry trucks, while Fig. 4 presents the visualization of the second harvesting system.

Total costs for forest operations with chainsaw cutting, tractor hauling and transport of roundwood with forestry trucks amount to $206.57 € / \mathrm{h}$ or $30.94 € / \mathrm{m}^{3}$. Total costs in the case of fully mechanized harvesting and transport of roundwood with forestry trucks amount, on the other hand, to $378.78 € / \mathrm{h}$ or $23.34 € / \mathrm{m}^{3}$. It should be noted that there are also working sites where fully mechanized harvesting is not highly efficient. In such situations, one should again refer to the cost calculations in order to select the most economically efficient harvesting system. In case of presented harvesting systems, the productivity rates were not considered. Default values proposed by WCM cost calculation tools were accepted. Default values gives user a rough estimation on productivity. Additional information on the proposed values are described in WCM cost calculation tools. Direct comparisons with default values can be subjective and one should note that for more objective comparison productivity rates shall be har-

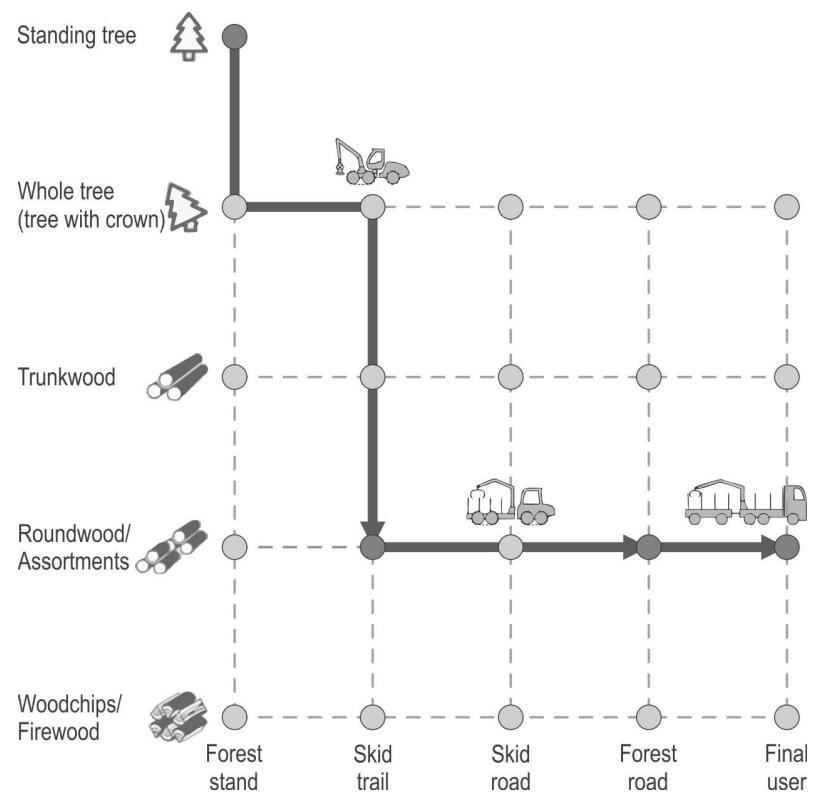

Fig. 4 Visualization of timber production with machine cutting and transport of roundwood with forestry trucks

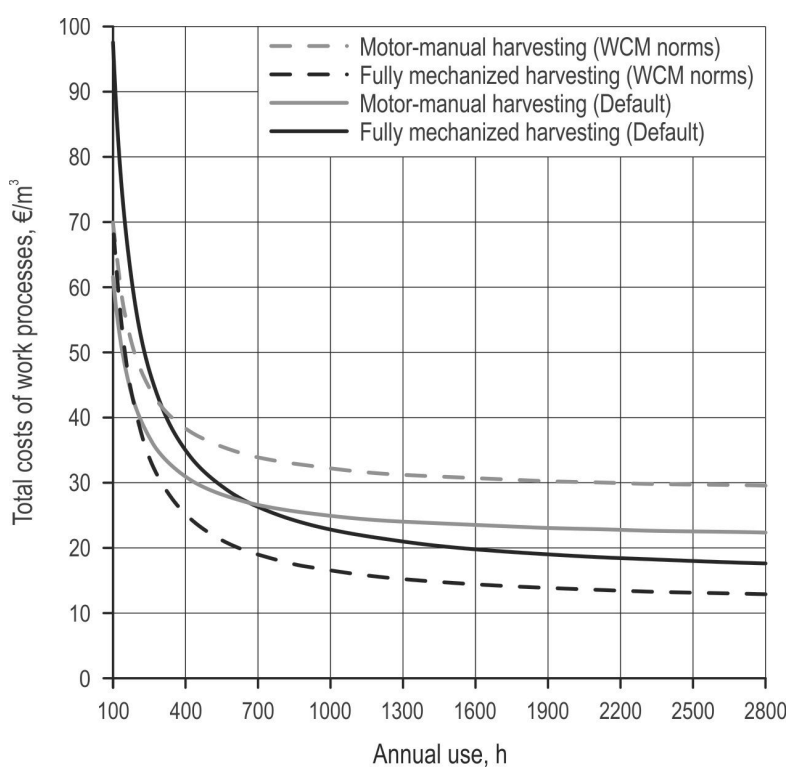

Fig. 5 Comparison of motor-manual harvesting and fully mechanized harvesting

monized. Using WCM norms tool, users have the ability to stipulate norms for different methods in comparable conditions. Fig. 5 presents the effect of productivity and annual use on the costs of harvesting system. Solid lines present costs where productivity rates are proposed by WCM cost calculation tool, while dashed lines present costs where productivity rates are harmonized using WCM norms tool.

\section{Discussion}

Forest harvesting and collection are labour-intensive and cost-burdensome activities. Monitoring of forest operation costs is very important for economic analysis, on the basis of which timber harvesting and operations can be rationalized along the entire production chain. This is very important, especially now at a time when a wide range of different technologies are available. The WoodChainManager Web-based tool deals with the majority of techniques used in forestry under conditions present in South-Eastern Europe. For all techniques, default values are provided for the calculation of costs. Users can adapt these default values relative to the characteristics of their own mechanization. Calculation of costs is crucial when deciding which technique to apply and enables optimization of forest operations. On the basis of calculations and uniform comparable inputs, justified and rational decisions for economic work can be made (Klun et al. 2009). In addition, it should be noted that forestry is one of those branches where the price of services is not 
based on supply and demand principles, but rather on the actual costs.

The presented Web application enables the preliminary calculation of timber production costs through visualization of the harvesting system. The selected method for calculating costs for individual machines is simple and transparent and reflects the state of the actually incurred costs. It should be noted that good calculations are based on the accuracy and actuality of input data across the whole production process and the regularity of the calculation method (Klun et al. 2009). Hence, it is important to be aware that calculations of costs are merely estimates. The precision of the output is a reflection of the accuracy of the input data, i.e. garbage in, garbage out (Ackerman et al. 2014). The calculation of costs supports our decisions. In reality, efficiency and costs, expressed per accounting unit, are strongly influenced by other factors (such as the competence and skill of workers, organizational arrangement of work and the functionality of machines) that, however, are not taken into account in many calculation methods (Klun et al. 2009). These factors, particularly the machine operator's competence and organizational arrangement of work, are so influential that work with the same machine can be very economic or not at all (Winkler et al. 1994). It is, therefore, essential to also include the efficiency or productivity of individual technologies in the calculations, since in all other cases we should be aware that comparisons are only useful for orientation and are can be even misleading.

To compare the economic efficiency of different technologies, one should be able to determine the time consumption (per unit product) that arises as a consequence of the selected process. The direct relationship between product output and time input is called productivity. There are many variables that affect these relationships, such as technology, working techniques, operator skill, and forest stand and environmental conditions (Acuna et al. 2012). Forest work science thus remains a significant part of the profession and has major economic consequences (Košir 2001, Košir and Spinelli 2015, Košir et al. 2015, Klun et al. 2016). Using the tool for stipulating forest work norms, we can designate a technical norm that can be achieved in conditions defined by the user. The innovation of the WCM tool lies in the new approach and simplified way of stipulating forest work norms, where data on the number of trees selected for cutting according to tree species and diameter at breast height and some basic details on the technique and field conditions suffice. The tool stipulates the standard time needed for the felling and hauling of trees selected for cutting as well as the maximum standard time, i.e. extra time added to standard time to account for difficult working and site conditions.

Every new technique or technology has implications for productivity, which can have significant consequences. Forest work norms concern workers who are usually paid for performance, employers who need to monitor production costs on a regular basis, and forest owners who ultimately earn higher or lower income.

\section{Conclusions}

The development of the online tool went through several phases, from the idea of visualization of harvesting systems, to the methodology for the calculation of costs, and to forest work norms. The common goal of all these phases is the assessment of costs in the harvesting system. The authors of this paper wish to increase the awareness and understanding of cost calculations and to offer the possibility to directly compare different harvesting systems. The tool can support decisions. In view of the aforementioned fact that every technology, new machine or new form of work can reduce costs and increase productivity, it will become necessary to constantly upgrade the WCM and similar tools. Furthermore, entrepreneurs should constantly check internal entrepreneurial norms. Through the inclusion of companies into such research, numerous reliable data would be obtained, which would further enhance these types of tools on the basis of actual results. This, unfortunately, is not today's reality. Ackerman (2014) has ascertained that in the current competitive environment, fewer companies are providing access to their data on production costs.

There are, however, some possibilities for further development of the tool. Tools could be added to allow users to monitor the actual costs of maintenance and fuel consumption, costs of movement of equipment and costs of organization of work, which would enable more accurate calculation of costs. Much of this data could be captured directly from the machine's onboard computer and sent to the Web platform directly via Internet of Things (IoT) devices. Such monitoring systems are already present in forestry. In addition, a tool could include a part to estimate the environmental suitability of the selected machines in view of the stand conditions, general terrain conditions and expected working conditions (humidity, infrastructure) on worksites. Triplat (2015) has proposed a decision-making tool that considers the strength of soils based on ground bearing capacities as an important environmental criterion. Nominal ground pressure is foreseen 
as matching mobility criteria, as it has the advantage of being an easy-to-assess numeric parameter. From the point of view of the application design, the online tool could easily be extended. The bigger challenge would be to collect the data on ground bearing capacities. Last but not least are the indirect overall management costs that are not directly connected to harvesting operations, such as material costs that arise from company administration, wages for administrative personnel and public service obligations. Such costs can be included in the calculation on the basis of the determined coefficient of the necessary addition to the direct hourly rate of the work of the cutter, which would serve to cover indirect costs.

\section{Acknowledgements}

The WoodChainManager online tool was supported and carried out within the framework of the following international and national projects: NEWFOR (INTERREG - Alpine Space), SmartLogChains (IPA A/ SLO) and PER-LES.

\section{Reference}

Ackerman, P., Belbo, H., Eliasson, L., De Jong, A., Lazdins, A., Lyons, J., 2014: The COST model for calculation of forest operation costs. International Journal of Forest Engineering 25(1): 75-81. https://doi.org/10.1080/14942119.2014.903711

Acuna, M., Bigot, M., Guerra, S., Hartsough, B., Kanzian, C., Kärhä, K., Lindroos, O., Magagnotti, N., Roux, S., Spinelli, R., Talbot, B., Tolosana, E., Zormaier, F., 2012: Good practice guidelines for biomass production studies, COST Action FP0902 and CNR IVALSA, Siesto Fiorentino, Italy. Available at: http://www.forestenergy.org/pages/cost-action-fp0902/ good-practice-guidelines/ [Accessed 10 April 2018].

Akay, A.E., 1998: Estimating machine rates and production for selected forest harvesting machines operating in the western United States and determining the most economical machine combinations under representative conditions in Turkey. Oregon State University, College of Forestry, Forest Engineering Depert, 193 p.

Bilek, E.M., 2009: Machine cost analysis using the traditional machine-rate method and chargeout! (Lake Tahoe: Council on Forest Engineering (COFE) Conference Proceedings: Environmentally Sound Forest Operations), 13 p.

Cwiertnia, O., Hauer, H., Nemestothy, N., Preier, P., 2014: NEWFOR - BFW - Online-Forstmaschinendatenbank [Online]. Bundesforschungszentrum für Wald (BFW): Bundesforschungs- und Ausbildungszentrum für Wald, Naturgefahren und Landschaft (BFW). Available at: https://bfw.ac. at $/ \mathrm{fmdb} /$ maschinen.web?kat=AB\&lang=1 [Accessed $15 \mathrm{Au}-$ gust 2018].

Decree on the concession for the exploitation of forests owned by the Republic of Slovenia, 2010. Official Gazette of
RS, 98/10, 98/12, 62/13, 90/13 and 108/13. Available at: http:// pisrs.si/Pis.web/pregledPredpisa?id=URED5360

Deere \& Co. 2010: TimberCalc - Machine Cost Web Calculator [Online]. Available at: http://ebus.eame.deere.com/timbercalc/index.php?language=ENGLISH [Accessed $20 \mathrm{Au}-$ gust 2018].

Erler, J., Weiß, M., 2003: Netz-Darstellung von Arbeitsverfahren. Forsttechnische Informationen 54(9): 103-107.

Erler, J., Dög, M., 2009: Funktiogramme für Holzernteverfahren, der Beitrag erschien in den FTI 9-10: 14-17.

FAO, 1992: Cost Control in Forest Harvesting and Road Construction, FAO, Rome, Forestry papers 99, 16 p.

Klun, J., Košir, B., Krč, J., Medved, M., 2007: Primerjava metod kalkulacij stroškov gozdarske mehanizacije na primeru žičnice. Zbornik gozdarstva in lesarstva 82: 41-51.

Klun, J., Robek, R., Piškur, M., Košir, B., 2016: Ocena stroškov prevoza lesa z gozdarsko traktorsko polprikolico. Gozdarski vestnik 75(3): 119-135.

Klun, J., Sinjur, I., Medved, M., 2009: Katalog stroškov gozdarske mehanizacije 2009, Gozdarski inštitut Slovenije, Ljubljana. Available at: http://www.gozdis.si/data/katalog_ kalkulacij/Katalog_stroskov_gozdarske_mehanizacije_linki. pdf [Accesed 15 April 2018].

Košir, B., 2001: Work Study a Forgotten Scientific Branch in Forestry? Nova mehanizacija šumarstva 26(2): 17-22.

Košir, B., Magagnotti, N., Spinelli, R., 2015: The role of work studies in forest engineering: status and perspectives. International Journal of Forest Engineering 26(3): 160-170. https:// doi.org/10.1080/14942119.2015.1111043

Košir, B., Spinelli, R., 2015: Pogledi na študij dela v okviru gozdne tehnike. Gozdarski vestnik 73(9): 369-391.

Krč, J., Košir, B., 2004: Stroški dela v različicah delovnih pogojev in izkoriščenosti strojev za sečnjo. Zbornik gozdarstva in lesarstva 75: 105-120.

Lan, Z., 2001: A cost model for forest machine operation in wood cutting and extraction. Development of a Protocol for Ecoefficient Wood Harvesting on Sensitive Sites, ECOWOOD, Helsinki, University of Helsinki, 15 p.

Matthews, D.M., 1942: Cost control in the logging industry. New York, McGraw-Hill book company, 374 p.

Miyata, E.S., 1980: Determining fixed and operating costs of logging equipment. Minnesota, North central forest experiment station, Forest service, U.S. Department of Agriculture, $21 \mathrm{p}$.

Nemestothy, N., Czwiertnia, O., Frutig, F., Thees, O., 2014: English glossary for estimating the costs of cable crane operations with »HeProMo«, the wood harvesting productivity model from WSL. NEW technologies for a better mountain FORest timber mobilization (Workpackage: Costs and benefits - WP 7), $27 \mathrm{p}$.

Österreichisches Kuratorium für Landtechnik und Landdenwicklung (ÖKL), 2014: Richtwerte 2014, Wien, 16 p. 
Pilz, S., Erler, J., 2017: Cost calculation to determine the forest operations costs. FORMEC, $27^{\text {th }}$ September 2017, Brașov, $37 \mathrm{p}$.

Rules on the list of agricultural and forestry machinery and the catalogue of costs of agricultural and forestry machinery, 2016. Official Gazette of RS. 7/16. Available at: http://www. pisrs.si/Pis.web/pregledPredpisa?id=PRAV12694

Sperandio, G., 2010: Costing forest machinery: available methods, recurrent problems. Harvesting forest biomass: a global state of the art. COST Action FP0902, $8^{\text {th }}$ October, Trento, Italy, $25 \mathrm{p}$.

Sundberg, U., Silversides C.R., 1988: Operational efficiency in forestry. Doordrecht, Netherlends, 219 p.
Triplat, M., Krajnc, N., Robek, R., 2013: Izbira tehnološkega modela pri proizvodnji zelenih sekancev. Gozdarski inštitut Slovenije, Ljubljana, $30 \mathrm{p}$.

Triplat, M., Prislan, P., Kranjc, N., 2015: Decision-making tool for cost-efficient and environmentally friendly wood mobilisation. SEEFOR 6(2): 179-190. http://dx.doi. org/10.15177/seefor.15-16

WCM WoodChainManager, 2018: Web portal WoodChainManager. Available at: http://wcm.gozdis.si [Accessed 20 August 2018].

Winkler, I., Košir, B., Krč, J., Medved, M., 1994: Kalkulacije stroškov gozdarskih del. Silva Slovenica, Gozdarski inštitut Slovenije, Ljubljana, 67 p.

(C) 2019 by the authors. Submitted for possible open access publication under the terms and conditions of the Creative Commons Attribution (CC BY) license (http://creativecommons.org/licenses/by/4.0/).

Received: October 18, 2018

Accepted: March 27, 2019
Authors' addresses:

Matevž Triplat, BSc *

e-mail: matevz.triplat@gozdis.si

Nike Krajnc, PhD

e-mail: nike.krajnc@gozdis.si

Slovenian Forestry Institute

Department for Forest Techniques and Economics

Večna pot 2

1000 Ljubljana

SLOVENIA

* Corresponding author 